DOI: https://doi.org/10.23925/ddem.i3.56741

Licença Creative Commons Atribuição 4.0 Internacional

\title{
A SUPRESSÃO DO JURIDIQUÊS
}

Luiz Gonzaga Bertelli ${ }^{1}$

Neologismo é uma palavra nova, importada de língua estrangeira ou formada no seio do vernáculo.

Juridiquês é um neologismo em voga no Brasil, a fim de designar o emprego desnecessário e excessivo do jargão jurídico e de termos técnicos do direito.

No dia 11 de agosto de 2005, a Associação dos Magistrados Brasileiros (AMB) efetuou o lançamento de uma campanha voltada à simplificação do juridiquês.

Recentemente, a imprensa noticia a atuação do titular da $6^{\text {a }}$ Vara da Justiça Federal do Rio Grande do Norte, especializada em execução fiscal.

O magistrado tem expedido mandados, cobrando as pessoas que deixaram de pagar os seus tributos e, em decorrência, a corrente bancária delas foi bloqueada.

As determinações emanadas da autoridade judicial, ao invés de empregar textos exaustivos e vocabulário complicado, redigido no latinório, estão limitadas apenas às poucas páginas, com ilustrações, para facilitar a compreensão - um vídeo de alguns minutos torna inteligível os processos.

O propósito da iniciativa do juiz é tornar fácil e clara a linguagem jurídica costumeira.

Ademais, o intento é que as deprecações não superem uma dezena de páginas, com a supressão de citações latinas desnecessárias e de difícil entendimento para o leigo.

Os defensores do denominado "juridiquês" apregoam que a preconizada ampliação causaria incontestáveis benefícios, com o maior acesso da população às informações jurídicas.

Numa pesquisa elaborada pelo Ministério Público do Rio de Janeiro (MPRJ), 98,8\% dos indagados asseveram tornar-se a documentação judiciária menos complexa e mais objetiva.

O intuito do mencionado jurista do Rio Grande do Norte já repercutindo em outros Estados, como Santa Catarina e Ceará: “A transformação digital já é uma realidade no mundo inteiro. No poder judiciário não é diferente", apregoa o juiz federal, Marco Bruno Miranda.

\footnotetext{
${ }^{1}$ Diretor Presidente da União dos Juristas Católicos de SP - UJUCASP. Presidente da Academia Paulista de História - APH

Revista Direitos Democráticos \& Estado Moderno |Faculdade de Direito da PUC-SP https://revistas.pucsp.br/index.php/DDEM | Nº. 03 | p.244-245 | Jul./Dez. 2021
} 
No ano de 2017, a promotoria de saúde do Rio de Janeiro elaborou um modelo resumido de petição inicial da Ação Civil Pública, recomendando a limitação da quantidade de páginas e, outrossim, que os documentos iniciem com um parágrafo, sintetizando os principais argumentos e concluam com a estruturação lógica da argumentação. Também, seriam eliminadas citações de trechos que não sejam alusivos à petição.

Para a promotoria do Ceará, deverão ser inseridas transformações para a melhor percepção da linguagem jurídica, embora muitos jurisconsultos ainda ignorem como se desfazer dessa linguagem.

Afinal, como apregoa o poeta: "A beleza encontra-se na simplicidade".

SP, novembro 2021. 